\title{
Effect of high-oleic-acid soybeans on production performance, milk fatty acid composition, and enteric methane emission in dairy cows
}

\author{
J. C. Lopes, ${ }^{*}$ M. T. Harper, ${ }^{*}$ F. Giallongo, ${ }^{*}$ J. Oh, ${ }^{*}$ L. Smith, ${ }^{*}$ A. M. Ortega-Perez, ${ }^{*}$ S. A. Harper, ${ }^{*}$ A. Melgar, ${ }^{*}$ \\ D. M. Kniffen, ${ }^{*}$ R. A. Fabin, $†$ and A. N. Hristov ${ }^{* 1}$ \\ *Department of Animal Science, The Pennsylvania State University, University Park 16802 \\ †Fabin Bros. Farms, Indiana, PA 15701
}

\begin{abstract}
The objective of this study was to investigate the effect of 3 soybean sources differing in fatty acid profile and processing method on productivity, milk composition, digestibility, rumen fermentation, and enteric methane emission in lactating dairy cows. The soybean sources were conventional, high-linoleic-acid variety extruded soybean meal (ESBM; 8.7\% ether extract with $15 \%$ oleic and $54 \%$ linoleic acids); extruded Plenish (DuPont Pioneer, Johnston, IA), high-oleic-acid variety soybean meal (EPSBM; $8.4 \%$ ether extract with $73 \%$ oleic and $8 \%$ linoleic acids); and whole, heated Plenish soybeans (WPSB; $20.2 \%$ ether extract). The study involved 15 Holstein cows in a replicated $3 \times$ 3 Latin square design experiment with three $28-\mathrm{d}$ periods. The inclusion rate of the soybean sources in the diet was (dry matter basis) 17.1, 17.1, and 7.4\% for ESBM, EPSBM, and WPSB, respectively, which resulted in ether extract concentration of the diets of $3.99,3.94$, and $4.18 \%$, respectively. Compared with ESBM, the Plenish diets tended to increase dry matter intake and decreased feed efficiency (but had no effect on energy-corrected milk feed efficiency). The Plenish diets increased milk fat concentration on average by $5.6 \%$ and tended to increase milk fat yield, compared with ESBM. The WPSB diet tended to increased milk true protein compared with the extruded soybean meal diets. Treatments had no effect on rumen fermentation and enteric methane or carbon dioxide emissions, except $\mathrm{pH}$ was higher for WPSB versus EPSBM. The Plenish diets decreased the prevalence of Ruminococcus and increased that of Eubacterium and Treponema in whole ruminal contents. Total-tract apparent digestibility of organic matter and crude protein were decreased by WPSB compared with ESBM and EPSBM. Compared
\end{abstract}

Received August 23, 2016.

Accepted October 24, 2016

${ }^{1}$ Corresponding author: anh13@psu.edu with the other treatments, urinary $\mathrm{N}$ excretion was increased by EPSBM and fecal $\mathrm{N}$ excretion was greater for WPSB. Treatments had marked effects on milk fatty acid profile. Generally, the Plenish diets increased mono-unsaturated (mostly cis-9 18:1) and decreased polyunsaturated, total trans-, and conjugated linoleic fatty acids concentrations in milk fat. In this study, compared with conventional, high-linoleic-acid variety extruded soybean meal, the Plenish soybean diets increased milk fat concentration and tended to increase fat yield, decreased feed efficiency, and modified milk fatty acid profile in a manner expected from the greater concentration of oleic acid in Plenish soybean oil.

Key words: high-oleic-acid soybean, milk fat, dairy cow

\section{INTRODUCTION}

The production benefits of inclusion of extruded oilseed meals in the diet of lactating dairy cows may come from (1) increased energy intake (due to higher oil content of extruded vs. solvent-extracted meals), (2) increased RUP (the extrusion process generates heat that increases the RUP content of the meal), and (3) increased DMI due to increased palatability or increased digestible AA intake. The production responses to extruded oilseed meals, however, have been variable (Socha, 1991; Santos et al., 1998). In a study related to the current experiment, we observed a $1.25-\mathrm{kg} / \mathrm{d}$ increase in DMI and a corresponding $3.25-\mathrm{kg} / \mathrm{d}$ increase in milk yield in dairy cows fed soybean meal (SBM) extruded at 2 temperatures versus the control, solvent-extracted SBM (Giallongo et al., 2015). It is worth noting that the extruded SBM increased plasma concentration of His, an AA that has been positively related to DMI in dairy cows (Lee et al., 2012; Giallongo et al., 2016). In the experiment of Giallongo et al. (2015), the extruded meals were included at $13 \%$ of dietary DM and had no statistical effect on milk fat concentration, although there was a numerical decrease of about 0.2 percentage units at both extrusion temperatures compared with the control. 
The oil of conventional soybean varieties contains a high concentration of 18:2 (and 18:3), the biohydrogenation of which is responsible for formation of CLA isomers known to cause milk fat depression (Baumgard et al., 2000; Moate et al., 2008). The modeling exercise of Moate et al. (2008) found that trans-10,cis-12 CLA concentration in milk fat was related to intestinal absorption of 18:2 (presumably mostly as cis-9, cis-12 18:2), whereas milk production of cis-9 18:1 or total trans-18:1 was related to $18: 1$ absorption. The role of 18:1 isomers in milk fat depression is debatable. Several studies have reported an association between trans-18:1, particularly trans-10 18:1, concentrations in milk fat and lowered milk fat synthesis (see Griinari et al., 1998; Bauman and Griinari, 2003). A study with abomasal infusion of trans-10 18:1, however, clearly demonstrated this isomer had no effect on milk fat concentration in dairy cows (Lock et al., 2007). A study by Hinrichsen et al. (2006) showed milk fat depression by highlinoleic-acid safflower oil, but no effect on milk fat by high-oleic-acid sunflower oil. Further, a meta-analysis by Glasser et al. (2008) suggested a greater negative effect on milk fat concentration by soybean oil (higher in 18:2) versus canola oil (higher in 18:1). Therefore, it is plausible that substitution of 18:2 with $18: 1$ in the diet may alleviate potential milk fat depression caused by high inclusion rates of extruded oilseed meals or even enhance milk fat synthesis in dairy cows. Additionally, increased intake of 18:1 results in increased MUFA concentration in milk fat (DePeters et al., 2001; Hristov et al., 2011a; Kliem et al., 2011), which may be beneficial for milk quality in terms of consumer perception (Jenkins and McGuire, 2006).

The current experiment was conducted to investigate the effect of 3 soybean sources differing in their fatty acid profile and processing method on productivity, milk composition, digestibility, rumen fermentation, and enteric methane emission in lactating dairy cows. Our main hypothesis was that substitution of conventional extruded SBM (predominantly 18:2) with extruded SBM high in 18:1 will increase milk fat synthesis and MUFA concentration in milk fat.

\section{MATERIALS AND METHODS}

All procedures carried out in the experiment were approved by the Animal Care and Use Committee at The Pennsylvania State University.

\section{Animals and Experimental Design}

The experiment was a replicated $3 \times 3$ Latin square design balanced for residual effects and was conducted in the tiestall barn of The Pennsylvania State Univer- sity's Dairy Teaching and Research Center. Fifteen multiparous lactating Holstein cows, averaging $2.6 \pm$ 0.22 lactations, $53 \pm 7.7 \mathrm{DIM}$, and $641 \pm 12.5 \mathrm{~kg}$ of BW at the beginning of the study, were grouped into 5 squares based on DIM, milk yield, and parity. Six cows (2 squares) were fitted with 10-cm (internal diameter) soft plastic ruminal cannulas (Bar Diamond Inc., Parma, ID). Each experimental period lasted 28 d, with $21 \mathrm{~d}$ of adaptation to the diets followed by $7 \mathrm{~d}$ of data and sample collection. Cows within square were randomly assigned to 1 of 3 treatment diets containing conventional variety, high-linoleic-acid extruded SBM (ESBM), extruded Plenish (DuPont Pioneer, Johnston, IA), high-oleic-acid variety SBM (EPSBM), or whole, heated Plenish soybeans (WPSB). Chemical composition of the soybeans is shown in Table 1. Diets (Table 2) were formulated to meet or exceed the NRC (2001) nutrient requirements for lactating Holstein cows yielding $42 \mathrm{~kg}$ of milk/d with $3.70 \%$ milk fat and $3.05 \%$ true protein at $27 \mathrm{~kg} / \mathrm{d}$ of DMI and $660 \mathrm{~kg}$ of BW. At the inclusion rate of the 3 soybean sources, the diets contained 1.5, 1.4, and 1.9\% soybean oil for ESBM, EPSBM, and WPSB, respectively. The lower inclusion rate for WPSB was intended to maintain similar CP and ether extract concentrations among the 3 diets (see notes in Results and Discussion). The extruded SBM (ESBM and EPSBM) were produced by Fabin Bros. Farms (Indiana, PA) from conventional and Plenish varieties of whole soybeans, respectively. Extrusion temperature was set at $160^{\circ} \mathrm{C}\left(320^{\circ} \mathrm{F}\right)$. The whole Plenish soybeans were roasted (WPSB) by Groff's Grain Roasting, Inc. (Lewisburg, PA). Temperature of the beans leaving the roaster was measured and averaged $158^{\circ} \mathrm{C}\left(317 \pm 0.94^{\circ} \mathrm{F}\right)$. Beans were not steeped after roasting. The WPSB were stored whole and rolled using a Roskamp electric roller mill (California Pellet Mill Co., Waterloo, Iowa) before inclusion in the TMR. Diets were mixed using a Kuhn Knight model 3142 Reel Auggie Mixer Wagon (Kuhn Knight Inc., Brodhead, WI) and were fed once daily $(0630 \mathrm{~h})$ as TMR to achieve about $10 \%$ refusals. Cows in this experiment did not receive rbST.

\section{Sampling and Measurements}

Individual feed intake (on an as-fed basis) and milk yield of the cows were recorded daily throughout the experiment. Cow BW was also recorded daily for the entire experiment using AfiFarm 3.04E scale system (S.A.E. Afikim, Rehovot, Israel) while cows exited the milking parlor. Total mixed ration and refusals from each diet were sampled twice weekly and samples were composited (on an equal weight basis) by week and diet. Samples of individual forages and concentrate 
feeds were collected weekly. Forages were composited by experimental period, whereas one composite sample for the entire experiment was prepared for each concentrate feed ingredient. All samples were stored at $-20^{\circ} \mathrm{C}$, dried for $\mathrm{DM}$ determination at $55^{\circ} \mathrm{C}$ for $72 \mathrm{~h}$ in a forced-air oven, and ground with a Wiley Mill (1-mm screen; Thomas Scientific, Swedesboro, NJ) for further analyses. Dry matter intake was computed from the as-fed TMR intake using the DM content of the weekly composited TMR and refusals samples. Composite samples of individual feed ingredients were analyzed by wet chemistry methods for CP (AOAC International, 2000), amylase-treated NDF (Van Soest et al., 1991), ADF (AOAC International, 2000), fat (AOAC International, 2006), ash (AOAC International, 2000), minerals (AOAC International, 2000), and estimated NFC and $\mathrm{NE}_{\mathrm{L}}(\mathrm{NRC}, 2001)$ by Cumberland Valley Analytical Services (Maugansville, MD; analytical methods are available at http://www.foragelab.com/Resources/ Lab-Procedures). Samples were analyzed for starch following the procedure of Hall (2009). The analyzed com-

Table 1. Chemical ${ }^{1}$ (\% of DM) and fatty $\operatorname{acid}^{2}(\mathrm{~g} / 100 \mathrm{~g}$ of total fatty acids) composition of the soybean sources used in the experiment

\begin{tabular}{lccc}
\hline & \multicolumn{3}{c}{ Soybean source $^{3}$} \\
\cline { 2 - 4 } Item & ESBM & EPSBM & WPSB \\
\hline CP & 48.0 & 51.4 & 40.2 \\
RUP, ${ }^{4}$ \% of CP & 51.3 & 49.8 & 61.9 \\
NDF & 11.3 & 7.7 & 18.2 \\
ADF & 5.4 & 4.1 & 9.4 \\
Ash & 6.25 & 6.07 & 5.17 \\
Ca & 0.29 & 0.29 & 0.32 \\
P & 0.66 & 0.66 & 0.56 \\
Starch & 4.9 & 3.5 & 5.8 \\
Ether extract & 8.68 & 8.36 & 20.2 \\
Fatty acids & & & \\
14:0 & 0.08 & 0.05 & 0.05 \\
14:1 & 0.03 & 0.04 & 0.04 \\
16:0 & 12.1 & 7.54 & 6.96 \\
16:1 & 0.80 & 0.56 & 0.23 \\
18:0 & 4.55 & 4.04 & 4.25 \\
cis-9 18:1 & 15.3 & 73.2 & 75.4 \\
cis-11 18:1 & 1.24 & 1.78 & 1.63 \\
18:3 & 54.1 & 7.88 & 6.94 \\
20:0 & 9.73 & 2.33 & 2.37 \\
20:1 & 0.30 & 0.36 & 0.40 \\
20:2 & 0.02 & 0.03 & 0.03 \\
Others & 0.39 & 0.41 & 0.41 \\
I 0 & 0.13 & 0.14 & 0.13 \\
& 1.27 & 1.65 & 1.17 \\
\hline
\end{tabular}

${ }^{1}$ Analyzed by Cumberland Valley Analytical Services Inc. (Maugansville, MD) using wet chemistry methods.

${ }^{2}$ Analyzed following the procedure of Rico and Harvatine (2013).

${ }^{3} \mathrm{ESBM}=$ conventional variety extruded soybean meal; EPSBM = Plenish variety extruded soybean meal; WPSB $=$ Plenish variety whole, heated soybeans.

${ }^{4}$ Analyzed using the Streptomyces griseus protease method (Krishnamoorthy et al., 1983) by Cumberland Valley Analytical Services.
Table 2. Ingredients and chemical composition of the diets used in the experiment

\begin{tabular}{|c|c|c|c|}
\hline \multirow[b]{2}{*}{ Item } & \multicolumn{3}{|c|}{ Diet $^{1}$} \\
\hline & ESBM & EPSBM & WPSB \\
\hline \multicolumn{4}{|l|}{ Ingredient, $\%$ of DM } \\
\hline Corn silage $^{2}$ & 41.0 & 41.0 & 41.0 \\
\hline Alfalfa haylage $^{3}$ & 15.9 & 15.9 & 15.9 \\
\hline Grass hay $^{4}$ & 4.0 & 4.0 & 4.0 \\
\hline Cottonseed, hulls & 4.0 & 4.0 & 4.0 \\
\hline Corn grain, ground & 10.0 & 10.0 & 10.0 \\
\hline ESBM & 17.1 & - & - \\
\hline EPSBM & - & 17.1 & - \\
\hline WPSB & - & - & 7.4 \\
\hline SBM, solvent-extracted ${ }^{5}$ & - & - & 9.7 \\
\hline Optigen $^{6}$ & 0.3 & 0.3 & 0.3 \\
\hline Molasses $^{7}$ & 4.7 & 4.7 & 4.7 \\
\hline Mineral-vitamin premix $^{8}$ & 3.0 & 3.0 & 3.0 \\
\hline \multicolumn{4}{|l|}{ Composition, \% of DM } \\
\hline $\mathrm{CP}^{9}$ & 17.4 & 18.0 & 17.4 \\
\hline $\mathrm{RDP}^{10}$ & 8.9 & 9.1 & 11.0 \\
\hline RUP $^{10}$ & 8.5 & 8.9 & 6.3 \\
\hline $\mathrm{NDF}^{9}$ & 32.0 & 31.4 & 32.4 \\
\hline $\mathrm{ADF}^{9}$ & 22.8 & 22.6 & 23.2 \\
\hline Ether extract ${ }^{9}$ & 3.99 & 3.94 & 4.18 \\
\hline Starch $^{9}$ & 22.7 & 22.5 & 22.7 \\
\hline $\mathrm{NE}_{\mathrm{L}},{ }^{10} \mathrm{Mcal} / \mathrm{kg}$ & 1.55 & 1.54 & 1.53 \\
\hline $\mathrm{NE}_{\mathrm{L}}$ balance ${ }^{10} \mathrm{Mcal} / \mathrm{d}$ & 2.0 & 2.9 & 2.6 \\
\hline MP balance ${ }^{10} \mathrm{~g} / \mathrm{d}$ & 722 & 953 & 332 \\
\hline $\mathrm{NFC}^{10}$ & 42.4 & 42.6 & 40.8 \\
\hline $\operatorname{Ash}^{9}$ & 7.07 & 7.04 & 7.00 \\
\hline $\mathrm{Ca}^{9}$ & 0.94 & 0.94 & 0.98 \\
\hline $\mathrm{P}^{9}$ & 0.33 & 0.33 & 0.33 \\
\hline
\end{tabular}

${ }^{1} \mathrm{ESBM}=$ conventional variety extruded soybean meal; EPSBM $=$ Plenish variety extruded soybean meal; WPSB $=$ Plenish variety whole, heated soybeans.

${ }^{2}$ Corn silage was $38.7 \% \mathrm{DM}$ and (DM basis): $40.2 \% \mathrm{NDF}, 34.7 \%$ starch, and $6.8 \% \mathrm{CP}$.

${ }^{3}$ Alfalfa haylage was $46.2 \% \mathrm{DM}$ and (DM basis): $41.4 \% \mathrm{NDF}$ and $22.1 \%$ CP.

${ }^{4}$ Grass hay contained (DM basis): $74.0 \%$ NDF and $7.1 \%$ CP.

${ }^{5}$ Soybean meal solvent-extracted contained (DM basis): $53.5 \% \mathrm{CP}$ and $1.82 \%$ fat.

${ }^{6}$ Optigen is a slow-release urea (Alltech Inc., Nicholasville, KY).

${ }^{7}$ Molasses (Westway Feed Products, Tomball, TX) contained (DM basis): $3.9 \% \mathrm{CP}$ and $66 \%$ total sugar.

${ }^{8}$ The premix (Cargill Animal Nutrition, Cargill Inc., Roaring Spring, PA) contained (\%, as-is basis): trace mineral mix, 0.86; $\mathrm{MgO}(56 \%$ $\mathrm{Mg}$ ), 8.0; $\mathrm{NaCl}, 6.4$; vitamin ADE premix (Cargill Animal Nutrition, Cargill Inc.), 0.48; limestone, 37.2; selenium premix (Cargill Animal Nutrition, Cargill Inc.), 0.07; and dry corn distillers grains with solubles, 46.7; and Ca, $14.1 \%$; P, $0.39 \%$; $\mathrm{Mg}, 4.59 \%$; K, 0.44\%; S, $0.39 \%$; Se, $6.91 \mathrm{mg} / \mathrm{kg} ; \mathrm{Cu}, 362 \mathrm{mg} / \mathrm{kg}$; Zn, $1,085 \mathrm{mg} / \mathrm{kg} ; \mathrm{Fe}, 186 \mathrm{mg} / \mathrm{kg}$, vitamin A, 276,717 IU/kg; vitamin D, 75,000 IU $/ \mathrm{kg}$; and vitamin $\mathrm{E}$, $1,983 \mathrm{IU} / \mathrm{kg}$.

${ }^{9}$ Values calculated using the chemical analysis (Cumberland Valley Analytical Services Inc., Maugansville, MD) of individual feed ingredients of the diet. Starch was analyzed according to Hall (2009).

${ }^{10}$ Values estimated based on NRC (2001) using actual DMI, milk yield, milk composition, and BW of the cows throughout the trial. Protein fractions and protein digestion rate for ESBM/EPSBM and WPSB were as specified by NRC (2001) for expeller soybean meal and whole, heated soybean, respectively. 
position of the feed ingredients and their inclusion in the TMR was used to compute CP, NDF, ADF, starch, fat, $\mathrm{Ca}$, and $\mathrm{P}$ concentration of the diets. Balance of $\mathrm{NE}_{\mathrm{L}}$ and MP were estimated using NRC (2001) based on actual DMI, milk yield, milk composition, and BW of the cows during the experiment. Composite TMR samples were analyzed for indigestible NDF (iNDF), as described in Lee et al. (2012).

During the last week of each experimental period, 8 spot fecal and urine samples (approximately $500 \mathrm{~g}$ and $300 \mathrm{~mL} /$ sample, respectively) were collected in 3 consecutive days at intervals staggered in time to cover a $24 \mathrm{~h}$ period (as in Lee et al., 2012). Fecal samples were oven-dried at $65^{\circ} \mathrm{C}$ for $48 \mathrm{~h}$, ground through a 1-mm sieve, composited per cow and experimental period, and then analyzed for $\mathrm{DM}, \mathrm{OM}, \mathrm{CP}, \mathrm{NDF}, \mathrm{ADF}$, starch, and iNDF. Total-tract apparent digestibility of dietary nutrients was estimated using iNDF as an internal digestibility marker. Urine samples were processed and analyzed for allantoin, uric acid, creatinine, urea-N, and total $\mathrm{N}$ as described by Lee et al. (2012). Daily urine volume was calculated using creatinine as a marker, assuming a creatinine excretion rate of 29 $\mathrm{mg} / \mathrm{kg}$ of BW (based on Hristov et al., 2011b), and was used to estimate urinary $\mathrm{N}$ and purine derivative excretions.

Blood samples were collected from the tail vein or artery into heparinized vacutainers at 4 and $8 \mathrm{~h}$ after feeding in $1 \mathrm{~d}$ during wk 3 of each experimental period. Blood plasma was separated and processed (Lee et al., 2012) for analysis of glucose and urea-N (Stanbio Glucose kit 1070 and Urea Nitrogen Kit 0580, respectively; Stanbio Laboratory Inc., Boerne, TX).

Milk samples were collected from 2 consecutive milkings (evening and morning) on 2 separate days (i.e., 4 milkings) during wk 4 of each experimental period. Milk samples were preserved with 2-bromo-2-nitropropane-1,3 diol and submitted to Dairy One Laboratory (Pennsylvania DHIA, University Park, PA) for analysis of fat, true protein, lactose, and MUN using infrared spectroscopy (MilkoScan 4000; Foss Electric, Hillerød, Denmark). Evening and morning milk samples were analyzed separately so milk component concentrations could be weighted for evening and morning milk yields. A separate unpreserved milk sample (from all 4 milkings) was stored at $-20^{\circ} \mathrm{C}$ and a composite, on an equal volume basis, sample was analyzed for fatty acids as described elsewhere (Rico and Harvatine, 2013).

Samples of whole ruminal contents were collected from the cannulated cows at 2, 4, 6, and $10 \mathrm{~h}$ after feeding in $1 \mathrm{~d}$ during wk 4 of each experimental period. These samples were collected, processed, and analyzed for $\mathrm{pH}$, ammonia, VFA, and protozoal counts as described in Hristov et al. (2010). Aliquots of whole ruminal contents were immediately preserved by freezing at $-80^{\circ} \mathrm{C}$ and later composited (as-is weight basis) and analyzed for microbial composition as described in Lopes et al. (2016).

Enteric methane and carbon dioxide emissions were measured during wk 4 of each experimental period using the GreenFeed system (C-Lock Inc., Rapid City, $\mathrm{SD})$. Measurements occurred 8 times in $3 \mathrm{~d}$ covering a 24-h period as follows: starting at 0900, 1500, and 2100 $\mathrm{h}$ (sampling d 1), 0300, 1200, and $1700 \mathrm{~h}$ (sampling d 2), and 0000, and $0500 \mathrm{~h}$ (sampling d 3). Duration of each measurement event (for all cows) was 100 to 110 min. Gas measurements were performed as described by Hristov et al. (2015a). A rumen cannula extension (fistula attachment; C-Lock Inc.) was used to direct potentially leaking rumen gas from the cannula into the GreenFeed unit. Construction and operation of the cannula extension are described in Lopes et al. (2016).

\section{Statistical Analysis}

All data were analyzed using the MIXED procedure of SAS (version 9.4, SAS Institute Inc., Cary, NC). Dry matter intake, milk yield, BW, milk composition, and rumen fermentation data were analyzed with day or sampling time as repeated measures assuming a Latin square design and an $\mathrm{AR}(1)$ covariance structure. The statistical model included treatment, experimental period, the repeated term, and treatment $\times$ period and treatment $\times$ repeated term interactions. Square and cow within square were random effects and all others were fixed. Remaining data (i.e., blood variables, nutrient digestibility, milk fatty acids, enteric gas emissions, and rumen microbial data) were analyzed with the previously described model excluding the repeated term and its interaction with treatment. Enteric gas emission data were averaged across all sampling points and the average values were used in the statistical analysis. The following preplanned contrasts were used to compare treatments: ESBM versus EPSBM, ESBM versus WPSB, EPSBM versus WPSB, and Plenish (i.e., EPSBM and WPSB) versus ESBM. Statistical differences were considered significant at $P \leq 0.05$ and a trend at $0.05<P \leq 0.10$. Data in tables are presented as least squares means.

\section{RESULTS AND DISCUSSION}

The composition of the soybean sources is shown in Table 1. As analyzed, EPSBM had higher CP and lower NDF than ESBM. The 2 extruded meals had similar ether extract concentration. Both ESBM and EPSBM had similar RUP, but RUP of WPSB was about $23 \%$ higher compared with the extruded SBM. Although 
Table 3. Effect of soybean fatty acid composition and processing method on feed DMI, milk production and composition, feed efficiency, and blood glucose and urea- $\mathrm{N}$ concentrations in dairy cows

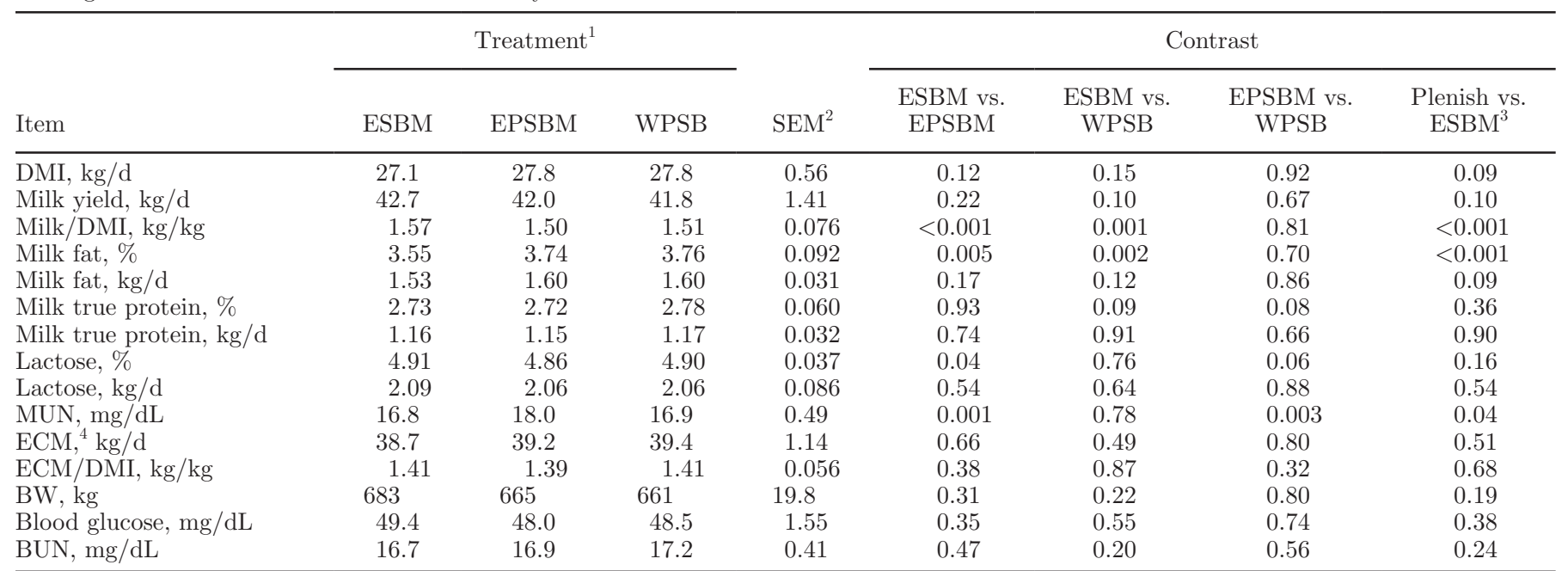

${ }^{1} \mathrm{ESBM}=$ conventional variety extruded soybean meal; EPSBM $=$ Plenish variety extruded soybean meal; WPSB $=$ Plenish variety whole, heated soybeans.

${ }^{2}$ Largest SEM published in table; DMI and milk yield, $\mathrm{n}=284$; milk yield/DMI, $\mathrm{n}=271 ; \mathrm{BW}, \mathrm{n}=116 ;$ milk composition data, $\mathrm{n}=84$, blood analyses, $\mathrm{n}=45$ ( $\mathrm{n}$ represents the number of observations used in the statistical analysis). Data are presented as LSM.

${ }^{3} \mathrm{EPSBM}$ and WPSB vs. ESBM.

${ }^{4}$ According to Sjaunja et al. (1990).

the RUP procedure used (Krishnamoorthy et al., 1983) may not accurately predict absolute RUP values, it is satisfactory for comparative purposes. The composition of WPSB was similar to table values for whole, heated soybeans (NRC, 2001). As expected, the fatty acid composition of the soybean sources reflected the higher concentration of 18:1 in the Plenish variety soybeans. Oil of the Plenish soybean sources had lower 16:0, similar 18:0, about 5 times greater cis-9 18:1, much lower 18:2, and lower 18:3 concentrations compared with the conventional variety ESBM.

The diets (Table 2) were designed to maximize the potential milk composition effects of the soybean sources while minimizing negative effects on rumen fermentation and DMI. The relatively high inclusion rate of the soybean sources resulted in diets with excess MP (balance of $>330 \mathrm{~g} / \mathrm{d}$ ). Due to differences between analyzed and anticipated composition of the soybean sources and variability in DMI during the experiment, daily intake of soybean oil was greater for WPSB than ESBM and EPSBM: on average 545, 402, and $397 \mathrm{~g} /$ cow per day, respectively. All diets supplied $\mathrm{NE}_{\mathrm{L}}$ in excess of estimated requirements (NRC, 2001).

The production data are shown in Table 3 . We noted a trend for higher $(P=0.09)$ DMI but lower $(P=0.10)$ milk yield with the Plenish soybean sources compared with ESBM. As a result, uncorrected for components feed efficiency was decreased $(P<0.001)$ for the Plenish diets versus ESBM. We observed no differences in
ECM yield or ECM feed efficiency among treatments. Milk fat concentration was increased $(P<0.001)$ and fat yield tended to be increased $(P=0.09)$ by both Plenish diets compared with ESBM. Milk true protein concentration was unusually low in this experiment but was similar among treatments, except it tended $(P \leq$ 0.09 ) to be slightly higher for WPSB compared with the extruded SBM diets. Lactose concentration tended to be lower $(P \leq 0.06)$ and MUN was higher $(P \leq$ 0.003 ) for EPSBM versus ESBM and WPSB. Blood glucose and BUN concentrations were similar among treatments.

Several studies have investigated the production effects of 18:1-rich vegetable oil supplemented in various forms (oil, oilseed meals, and crushed oilseeds) to the diets of dairy cows. In an early study, Casper et al. (1988) found no effect of conventional or high-18:1 sunflower seeds (up to $5-5.8 \%$ total dietary fat) on DMI or milk production. Similarly, no effect of peanut oil (high in 18:1) on milk yield was observed in a short, 2-wk period experiment with dairy cows (Kelly et al., 1998). A 5\% inclusion rate of high-18:1 safflower oil did not have an effect on DMI or milk production of Holstein cows in an extensive crossover experiment (He and Armentano, 2011). In another study from the same group, blends of 18:1 and 18:2 in different proportions (up to $4.1 \%$ added fat) had no effect on DMI or milk production in dairy cows (He et al., 2012). Kliem et al. (2011) reported no effect of conventional and high- 
18:1 rapeseed, included at up to $1,150 \mathrm{~g}$ of oil/d, on DMI and milk production compared with a commercial product based on $\mathrm{Ca}$ salts of fatty acids. Compared with soybean, canola or rapeseed oil is higher in 18:1, and several studies have reported effects of canola seeds or meals on productivity of dairy cows. Beauchemin et al. (2009), for example, found increased DMI but no effect on milk yield or feed efficiency of crushed canola seeds compared with high-18:2 (sunflower) or high-18:3 (flax) seeds. Inclusion of approximately 13\% high-18:1 extruded (13.7\% ether extract, $76.1 \%$ 18:1) canola meal decreased DMI but had no effect on milk yield and, thus, increased feed efficiency in high-producing dairy cows (Hristov et al., 2011a). A recent study reported a 1 to $2.5 \mathrm{~kg} / \mathrm{d}$ decrease in milk yield when the diet was supplemented with 3 to $6 \%$ canola oil $(58 \%$ 18:1; Welter et al., 2016). Surprisingly, however, DMI of the cows was not reported. Dry matter intake is the main determinant of milk production in lactating dairy cows (Hristov et al., 2004a) and dietary fat may, in certain situations, increase DMI or milk production. In our previous work with extruded SBM (10 to $11 \%$ ether extract), we reported increased DMI and milk yield when the extruded meal was included at $13 \%$ of dietary DM and total dietary fat was around 4.3\% (Giallongo et al., 2015). Depending on the basal diet, even at low inclusion rates, dietary fat may increase DMI in dairy cows. For example, Stoffel et al. (2015) reported increased milk yield and no effect on DMI when vegetable oil was included at $1.7 \%$ of DM (around $3 \%$ total fatty acids) in a 19\% CP alfalfa haylage-based diet. Overall, however, the effect of oilseeds, in one form or another, on DMI in dairy cows has been generally negative (Socha, 1991; Glasser et al., 2008). In their meta-analysis, Rabiee et al. (2012) reported an overall standardized mean difference between oilseeds and control (25 comparisons) of $-0.21 \mathrm{~kg}$ of $\mathrm{DMI} / \mathrm{d}$, although heterogeneity was high.

It is likely that the relatively low milk true protein concentration observed in our study was due to the high inclusion rate of high-fat soybean sources (although total fat was around $4 \%$ of dietary DM). Meta-analyses have shown that dietary fat, including from oilseeds, has a detrimental effect on milk protein concentration (Onetti and Grummer, 2004; Rabiee et al., 2012), likely a result of depressed microbial protein synthesis in the rumen. The higher MUN with the EPSBM diet can be explained with the greater CP concentration of EPSBM versus ESBM and WPSB diets. Supplementation of dairy diets with fat from oilseeds has generally resulted in decreased milk fat concentration, particularly with soybean and sunflower seeds and oil in the meta-analysis of Glasser et al. (2008). The meta-analysis of Rabiee et al. (2012) found a 0.33 percentage unit decrease in milk fat with oilseeds but heterogeneity was high
(72\%), similar to the effect on DMI. Others, however, have reported increased milk fat concentration with fat supplementation, depending on diet composition, forage type, and level of unsaturation of the supplemental fat (Schroeder et al., 2004; Weiss et al., 2011). In our related study, extruded SBM included at $13 \%$ of dietary DM numerically decreased milk fat concentration (by about 0.2 percentage units) compared with the control, solvent-extracted SBM (Giallongo et al., 2015). In the current study, the ESBM and EPSBM diets had a similar fat inclusion rate; therefore, it is safe to assume that the effect on milk fat with the Plenish diets was a result of differences in fatty acid composition among the soybean sources. These differences included higher 18:1 and lower 18:2 (and also 18:3) in the Plenish soybeans versus the conventional soybeans used for ESBM. In the study of He and Armentano (2011), 5\% vegetable oil (for a total of $6.8 \%$ fat in the diet) decreased milk fat concentration, independent of the oil source (i.e., predominantly 18:2 vs. predominantly 18:1). Those authors later tested lower inclusion rate of oil $(<3 \%$ of DM) and reported similar depression of milk fat by both high-18:2 and high-18:1 vegetable oil (Stoffel et al., 2015). The milk fat depression effect, however, was significantly greater with high-18:2 oil.

Concentration of trans-10 18:1 in milk fat was decreased by the Plenish treatments in the current study (see discussion below). Griinari et al. (1998) related diet effects (low fiber) and milk trans-10 18:1 concentration to milk fat depression. Concentration of trans-10 18:1 was also negatively related $\left(\mathrm{R}^{2}=0.53\right)$ to milk fat percent in a field study (Nydam et al., 2009). Milk concentrations of both trans-10 18:1 and trans-10,cis-12 CLA followed similar patterns during induced milk fat depression in a study by Rico and Harvatine (2013). The trans-10,cis-12 CLA isomer has been conclusively shown to cause milk fat depression (Baumgard et al., 2000), and a meta-analysis by Moate et al. (2008) identified estimated absorption of 18:2 (as an indicator of 18:2 outflow from the rumen) as the main factor determining output of trans-10, cis-12 CLA in milk. Thus, greater intake of 18:2, such as with the ESBM diet in the current study, is expected to be a precondition for potentially greater supply of trans-10, cis-12 CLA to the mammary gland. This CLA isomer, however, was not detected in milk from any of the cows in the current experiment. The Plenish diets decreased trans-10 18:1 (and other trans-18:1 isomers), but an abomasal infusion study clearly showed no effect of trans-10 18:1 on milk fat concentration (Lock et al., 2007). Thus, although the lowered concentration of trans-18:1 isomers in milk of cows fed the Plenish diets is in line with reports that found good relationships between these fatty acids and milk fat depression, it appears the greater 
milk fat concentration with EPSBM and WPSB in the current study was a result of the greater postruminal supply of 18:1 compared with ESBM. Average cis-9 18:1 yield was $59.5 \mathrm{~g} / \mathrm{cow}$ per day greater $(P<0.001)$ for the Plenish treatments compared with ESBM (322 vs. $263 \mathrm{~g} / \mathrm{d}$, respectively), whereas yields of 16:0 (412 to $440 \mathrm{~g} / \mathrm{d} ; P=0.18$ ) and $18: 0$ (190 to $192 \mathrm{~g} / \mathrm{d} ; P$ $=0.31$ ) were not different among treatments. Yields of PUFA or total trans-fatty acids were on average 31 $(43.2$ vs. $74.0 \mathrm{~g} / \mathrm{d} ; P<0.001)$ and $6.4 \mathrm{~g} / \mathrm{d}$ lower $(44.1$ vs. $50.5 \mathrm{~g} / \mathrm{d}$, respectively; $P<0.001)$ for the Plenish diets compared with ESBM (fatty acid yield data are not shown in tables). Thus, the increase in the yield of cis-9 18:1 was about $62 \%$ greater than the decrease in yield of the major fatty acid groups, such as PUFA and total trans-fatty acids, caused by EPSBM and WPSB, which was sufficient to explain the increase in milk fat percentage with these diets compared with ESBM.

Faldet and Satter (1991) pointed out that feeding whole roasted soybeans does not decrease milk fat concentration to the extent that extruded SBM does, attributing the effect to a lower availability of soybean oil with the former feed. This kind of effect was not observed in the current experiment; however, the WPSB diet provided considerably more supplemental fat than EPSBM, thus having a higher risk for ruminal disturbances and milk fat depression. The fact that milk fat concentration was not different between the Plenish diets provides indirect evidence that supplemental fat from WPSB causes less disturbance to ruminal fermentation than fat from free oil or extruded meals, which is in agreement with the conclusions of Faldet and Satter (1991). Chouinard et al. (1997) also found no differences in milk production or composition between extruded SBM and roasted soybeans included in the diet at a level similar to that in the current study. A similar lack of effect of roasting versus extrusion of soybeans on milk composition was reported earlier by Scott et al. (1991).

Intake and total-tract apparent digestibility of dietary nutrients in the current study are shown in Table 4 . Intake of nutrients was similar among diets $(P \geq 0.10)$, but DM and $\mathrm{OM}$ digestibility was lower $(P<0.001)$ for WPSB compared with the extruded SBM diets. The difference was about 2 to $3 \%$ for both DM and OM. Total-tract apparent digestibility of $\mathrm{CP}$ was also decreased $(P<0.001)$ by WPSB, compared with ESBM and EPSBM. Digestibility of DM, OM, and CP tended to be or were slightly higher $(P \leq 0.08)$ for EPSBM versus ESBM. Digestibility of the fiber fractions and starch was not affected by treatment. The likely explanation for the lower CP digestibility of WPSB versus the extruded SBM diets was the higher temperature input (supported by the higher RUP concentration of the WPSB feed) during roasting versus the extrusion process and the open-flame exposure versus indirect heating as a result of friction with the latter process. The processing temperatures of the extruded SBM and WPSB were intended to be similar (i.e., 158 to $160^{\circ} \mathrm{C}$ ); these 2 processes, however, are different in terms of time the beans are exposed to heat. The extruded meal passes through the die relatively rapidly, whereas, in the current study, the beans spent approximately $2 \mathrm{~min}$ in the roaster ( $1 \mathrm{~min}$ of which at the extreme heat at the top of the flame). Although the temperature of the soybeans measured when they exited the roaster was on average $158^{\circ} \mathrm{C}$, it is certain that they were exposed to higher temperatures within the roaster. Visual observation of the WPSB indicated that some beans were charred, apparently due to extreme heat within the roaster. Further, WPSB were rolled before inclusion in the TMR, whereas the extruded SBM were ground. This combination of temperature, time to heat exposure, and particle size likely resulted in the higher RUP content and lower digestibility of WPSB versus the extruded SBM feeds and diets. As fiber digestibility was not different among treatments, the difference in DM and $\mathrm{OM}$ digestibility between roasted and extruded soybean sources was a result of differences in digestibility of soybean CP and probably other nonfiber soluble fractions, such as sugars. Fat, among other dietary factors such as NFC and proportion of whole-crop silage, is known to decrease nutrient digestibility (Huhtanen et al., 2009), but few studies have examined the effect of oilseed processing on nutrient digestibility in dairy cattle. Similar to our data, Scott et al. (1991) reported decreased CP digestibility of roasted whole soybeans compared with extruded SBM. Those authors found no effect of treatment on NDF digestibility, but, unlike the current study, they also found no effect on DM or OM digestibility (only numerical decreases with the roasted soybean diet).

Urinary and fecal $\mathrm{N}$ excretion and milk $\mathrm{N}$ secretion data are shown in Table 5. Absolute milk true protein secretion (during the week of digestibility and urine sample collections) was not different among treatments but as a percentage of $\mathrm{N}$ intake was slightly lower $(P$ $=0.05)$ for the Plenish soybean sources compared with ESBM. Urinary and urea $\mathrm{N}$ excretions were increased $(P \leq 0.04)$ by EPSBM versus WPSB and fecal N excretion was greater $(P<0.001)$ for WPSB compared with both extruded meal diets. This was a result of the higher concentration and intake of CP in the EPSBM diet and lower CP digestibility and higher RUP of WPSB (as discussed above), respectively. The Plenish diets had higher $(P=0.03)$ total $\mathrm{N}$ excretion in urine and feces than ESBM and, compared with the other treatments, the WPSB diet increased or tended 
Table 4. Effect of soybean fatty acid composition and processing method on intake and total-tract apparent digestibility of nutrients in dairy cows

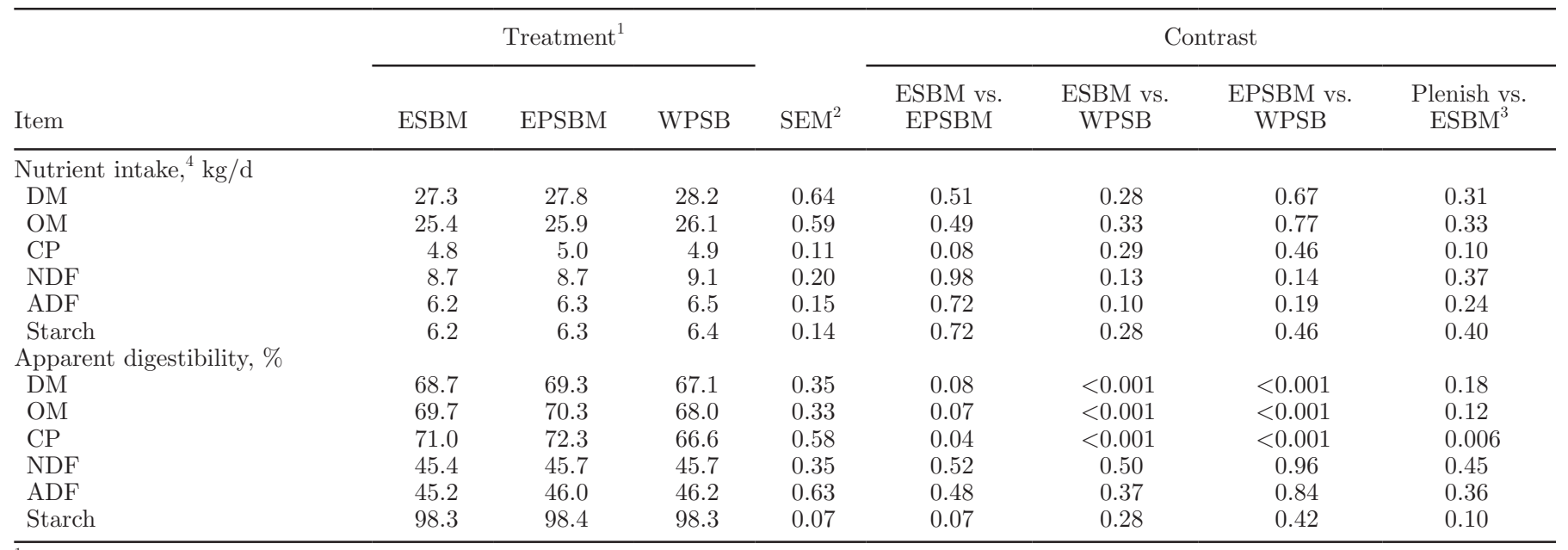

${ }^{1} \mathrm{ESBM}=$ conventional variety extruded soybean meal; EPSBM $=$ Plenish variety extruded soybean meal; WPSB $=$ Plenish variety whole, heated soybeans.

${ }^{2}$ Largest SEM published in table; $\mathrm{n}=45$ ( $\mathrm{n}$ represents number of observations used in the statistical analysis). Data are presented as LSM. ${ }^{3}$ EPSBM and WPSB vs. ESBM

${ }^{4}$ Intake data during the digestibility measurement periods.

to increase $(P \leq 0.08) \mathrm{N}$ excretions as proportion of $\mathrm{N}$ intake. Excretion of purine derivatives, as markers of rumen microbial protein synthesis and outflow, was not affected by treatment in this experiment.
Rumen fermentation data are shown in Table 6 . Rumen $\mathrm{pH}$ was higher $(P=0.04)$ for WPSB versus EPSBM. Concentration of ammonia and total VFA in ruminal fluid was not different among treatments,

Table 5. Effect of soybean fatty acid composition and processing method on milk $\mathrm{N}$ secretion, urinary and fecal $\mathrm{N}$ excretion, and urinary purine-derivative excretion in dairy cows ${ }^{1}$

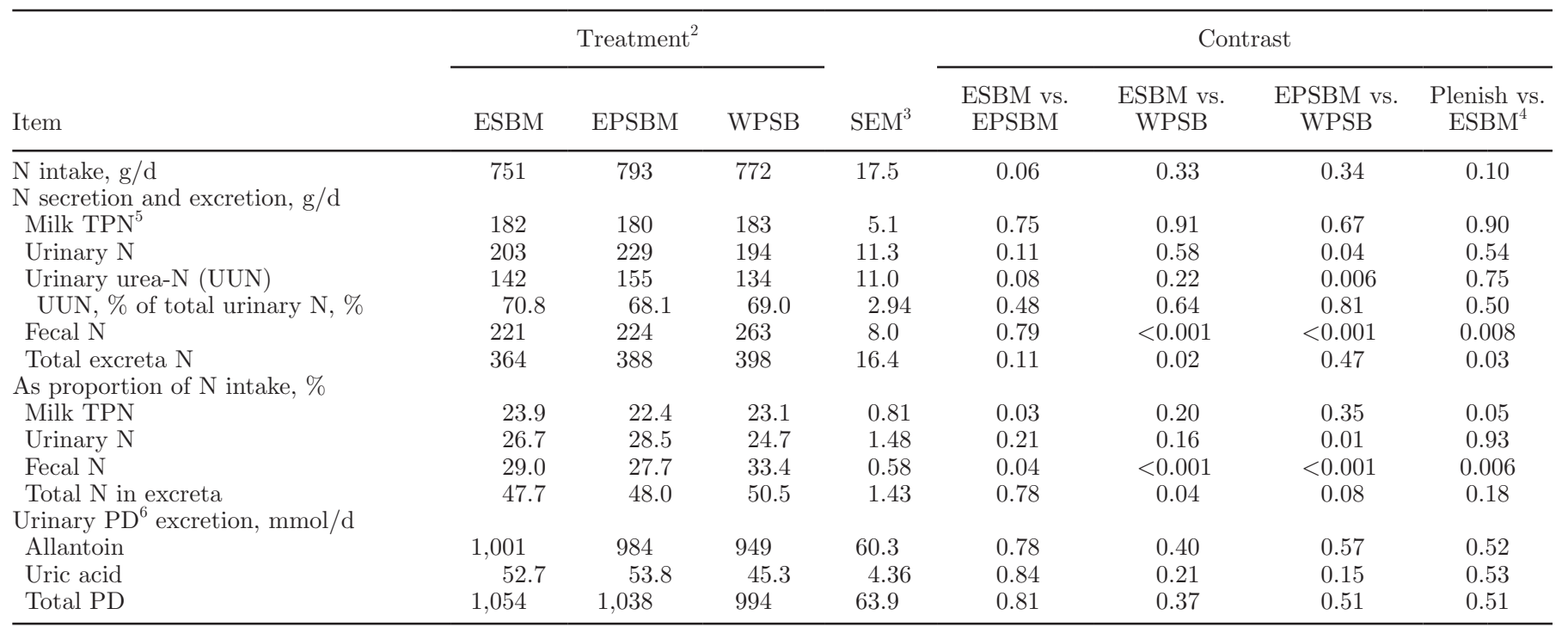

${ }^{1}$ All data are for the experimental week during which fecal and urine samples were collected.

${ }^{2} \mathrm{ESBM}=$ conventional variety extruded soybean meal; EPSBM $=$ Plenish variety extruded soybean meal; WPSB $=$ Plenish variety whole heated soybeans.

${ }^{3}$ Largest SEM published in table; $\mathrm{n}=45$ ( $\mathrm{n}$ represents number of observations used in the statistical analysis). Data are presented as LSM. ${ }^{4}$ EPSBM and WPSB vs. ESBM.

${ }^{5}$ Milk true protein $\mathrm{N}$ (milk true protein $\div 6.38$ ).

${ }^{6} \mathrm{PD}=$ purine derivatives. 
but the molar proportion of propionate was decreased $(P \leq 0.02)$ by WPSB compared with the extruded meals, which resulted in a trend for greater $(P \leq 0.09)$ acetate-to-propionate ratio for WPSB. The proportion of isovalerate tended to be higher $(P=0.08)$ for the Plenish treatments compared with ESBM. Protozoal counts were not affected by treatment. Our earlier work showed a clear trend for decreased acetate concentration when high-oil extruded canola and rapeseed meals were included in the diet of dairy cows (Hristov et al., 2011a). High level of oil supplementation results in depressed rumen fermentation and decreased VFA concentrations (Jenkins, 1993; Harfoot and Hazlewood, 1997), but fatty acid profile does not usually have a profound effect of VFA composition (Palmquist, 1991) unless fermentation is severely inhibited (Hristov et al., 2004b, 2011b; Lee et al., 2011). Casper et al. (1988) reported increased acetate and decreased propionate proportions in the rumen fluid of cows fed high-18:1 versus conventional, high-18:2 sunflower seeds. Such an effect of 18:1 (i.e., Plenish treatments) was not observed in the current study. Beauchemin et al. (2009) did not find differences in rumen VFA concentrations as a result of feeding oilseeds with various fatty acid compositions (18:1 vs. 18:2 vs. 18:3). Surprisingly, some studies reported increased acetate concentration with high levels of UFA supplementation (from soybean and linseed oils; Szumacher-Strabel et al., 2002).

Diet had no effect on enteric methane emission in this experiment (Table 7). Methane emission yield (i.e., per unit of DMI) or intensity (per unit of ECM) and carbon dioxide emissions were also not affected by treatment. Methane emissions were within the range of emissions for high-producing dairy cows observed in our laboratory using different measurement techniques (Hristov et al., 2015b, 2016). Hydrogen emission was negligible in this experiment (on average $<2 \mathrm{mg} / \mathrm{cow}$ per day; data not shown). Overall, fatty acid composition of dietary fat does not seem to have a well-defined effect on enteric methane emission. Some earlier reports suggested greater inhibition of methane production (and Methanobacterium ruminantium growth) by 18:1 compared with other medium- or long-chain fatty acids in pure culture (Henderson, 1973). In a meta-analysis, Grainger and Beauchemin (2011) indicated that enteric methane yield was not affected by form of added fat, major fatty acid in the added fat, or fat source. Other analyses have shown that medium-chain SFA (such as 12:0) and PUFA (such as 18:3) are more potent methane inhibitors that other dietary fatty acids (Doreau et al., 2011; Patra, 2013).

In agreement with the methane emission data, we found no effect of treatment on rumen archaea (Table 8). The prevalence of several bacterial genera, however, was affected by the soybean source in this experiment. Prevotella, major rumen bacteria, were decreased $(P$ $\leq 0.08)$ by EPSBM compared with the other treatments. Overall, differences in bacterial genus composition between EPSBM and WPSB were insignificant. The proportions of Ruminococcus and Succiniclasticum (including Succiniclasticum ruminis; data not shown) were decreased $(P \leq 0.04)$ and those of Eubacterium, Treponema, and Thioalkalibacter (including Thioalkalibacter halophilus; data not shown) were increased ( $P$ $\leq 0.03)$ by the Plenish diets compared with ESBM. Henderson (1973) reported inhibitory effects of an ar-

Table 6. Effect of soybean fatty acid composition and processing method on rumen fermentation in dairy cows

\begin{tabular}{|c|c|c|c|c|c|c|c|c|}
\hline \multirow[b]{2}{*}{ Item } & \multicolumn{3}{|c|}{ Treatment $^{1}$} & \multirow[b]{2}{*}{$\mathrm{SEM}^{2}$} & \multicolumn{4}{|c|}{ Contrast } \\
\hline & ESBM & EPSBM & WPSB & & $\begin{array}{c}\text { ESBM vs. } \\
\text { EPSBM }\end{array}$ & $\begin{array}{c}\text { ESBM vs. } \\
\text { WPSB }\end{array}$ & $\begin{array}{c}\text { EPSBM vs. } \\
\text { WPSB }\end{array}$ & $\begin{array}{c}\text { Plenish vs. } \\
\text { ESBM }^{3}\end{array}$ \\
\hline $\mathrm{pH}$ & 5.94 & 5.91 & 6.01 & 0.042 & 0.45 & 0.17 & 0.04 & 0.72 \\
\hline Ammonia, $\mathrm{m} M$ & 4.56 & 4.87 & 4.48 & 0.23 & 0.34 & 0.83 & 0.25 & 0.67 \\
\hline Total VFA, $\mathrm{m} M$ & 112 & 110 & 109 & 2.92 & 0.59 & 0.38 & 0.73 & 0.42 \\
\hline \multicolumn{9}{|c|}{ As $\%$ of total fatty acids } \\
\hline Acetate & 63.3 & 63.0 & 63.7 & 0.66 & 0.56 & 0.38 & 0.15 & 0.86 \\
\hline Propionate & 19.7 & 19.7 & 19.1 & 0.67 & 0.89 & 0.02 & 0.01 & 0.19 \\
\hline Butyrate & 12.1 & 12.3 & 12.1 & 0.27 & 0.59 & 0.86 & 0.71 & 0.68 \\
\hline Isobutyrate & 1.16 & 1.14 & 1.23 & 0.042 & 0.82 & 0.35 & 0.24 & 0.68 \\
\hline Valerate & 2.00 & 2.02 & 1.95 & 0.071 & 0.75 & 0.27 & 0.16 & 0.65 \\
\hline Isovalerate & 1.81 & 1.88 & 1.90 & 0.041 & 0.18 & 0.09 & 0.71 & 0.08 \\
\hline Acetate:propionate & 3.26 & 3.24 & 3.37 & 0.145 & 0.72 & 0.09 & 0.04 & 0.43 \\
\hline Protozoa, ${ }^{4} \times 10^{4} / \mathrm{mL}$ & 35.5 & 33.8 & 41.1 & 4.6 & 0.77 & 0.37 & 0.25 & 0.72 \\
\hline
\end{tabular}

${ }^{1} \mathrm{ESBM}=$ conventional variety extruded soybean meal; EPSBM = Plenish variety extruded soybean meal; WPSB $=$ Plenish variety whole, heated soybeans.

${ }^{2}$ Largest SEM published in table; $\mathrm{n}=72$ ( $\mathrm{n}$ represents number of observations used in the statistical analysis). Data are presented as LSM.

${ }^{3}$ EPSBM and WPSB vs. ESBM.

${ }^{4}$ Actual protozoal counts were $\log 10$-transformed for the statistical analysis. 
Table 7. Effect of soybean fatty acid composition and processing method on carbon dioxide $\left(\mathrm{CO}_{2}\right)$ and methane $\left(\mathrm{CH}_{4}\right)^{1}$ emissions in dairy cows

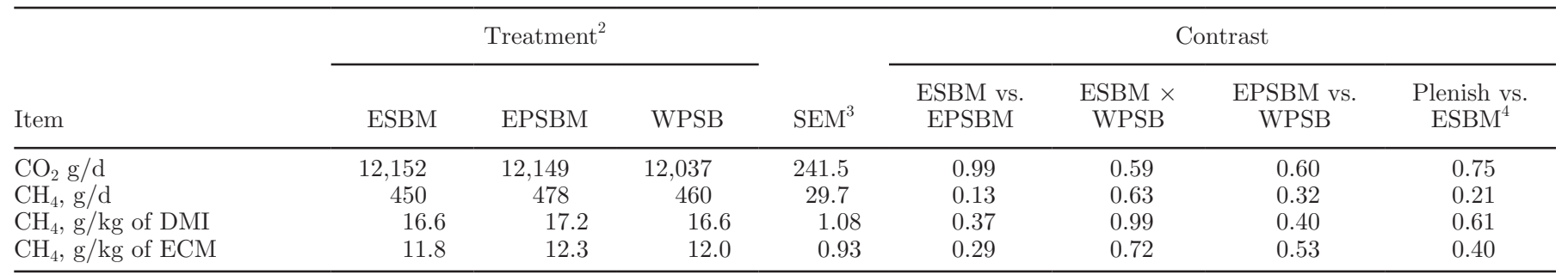

${ }^{1}$ Rumen gas emissions were measured using GreenFeed (C-Lock Technology Inc., Rapid City, SD). Data were derived from 8 individual measurements staggered over a 3 -d period.

${ }^{2} \mathrm{ESBM}=$ conventional variety extruded soybean meal; EPSBM $=$ Plenish variety extruded soybean meal; WPSB $=$ Plenish variety whole, heated soybeans.

${ }^{3}$ Largest SEM published in table. $\mathrm{CO}_{2}, \mathrm{n}=42 ; \mathrm{CH}_{4}, \mathrm{n}=38 ; \mathrm{CH}_{4} / \mathrm{DMI}, \mathrm{n}=39 ; \mathrm{CH}_{4} / \mathrm{ECM}, \mathrm{n}=37$ (n represents the number of observations used in the statistical analysis). Data are presented as LSM.

${ }^{4}$ EPSBM and WPSB vs. ESBM.

ray of fatty acids (particularly 12:0 and 18:1) on $R u$ minococcus, which is in agreement with results for the Plenish soybean sources in the current study. A similar inhibitory effect of 18:1 on rumen cellulolytic species was reported by Maczulak et al. (1981). Polyunsaturated fatty acids have been shown to be toxic to several important rumen bacteria, including major players in rumen biohydrogenation of dietary fatty acids such as Butyrivibrio fibrisolvens (Maia et al., 2010). The decreased prevalence of Succiniclasticum (specifically Succiniclasticum ruminis, bacteria converting succinate to propionate in the rumen; van Gylswyk, 1995) observed in our experiment for the Plenish diets, but more pronounced with WPSB, is in line with the slightly lower

Table 8. Effect of soybean fatty acid composition and processing method on rumen archaeal and bacterial genus composition (as \% of total isolates $^{1}$ ) in dairy cows

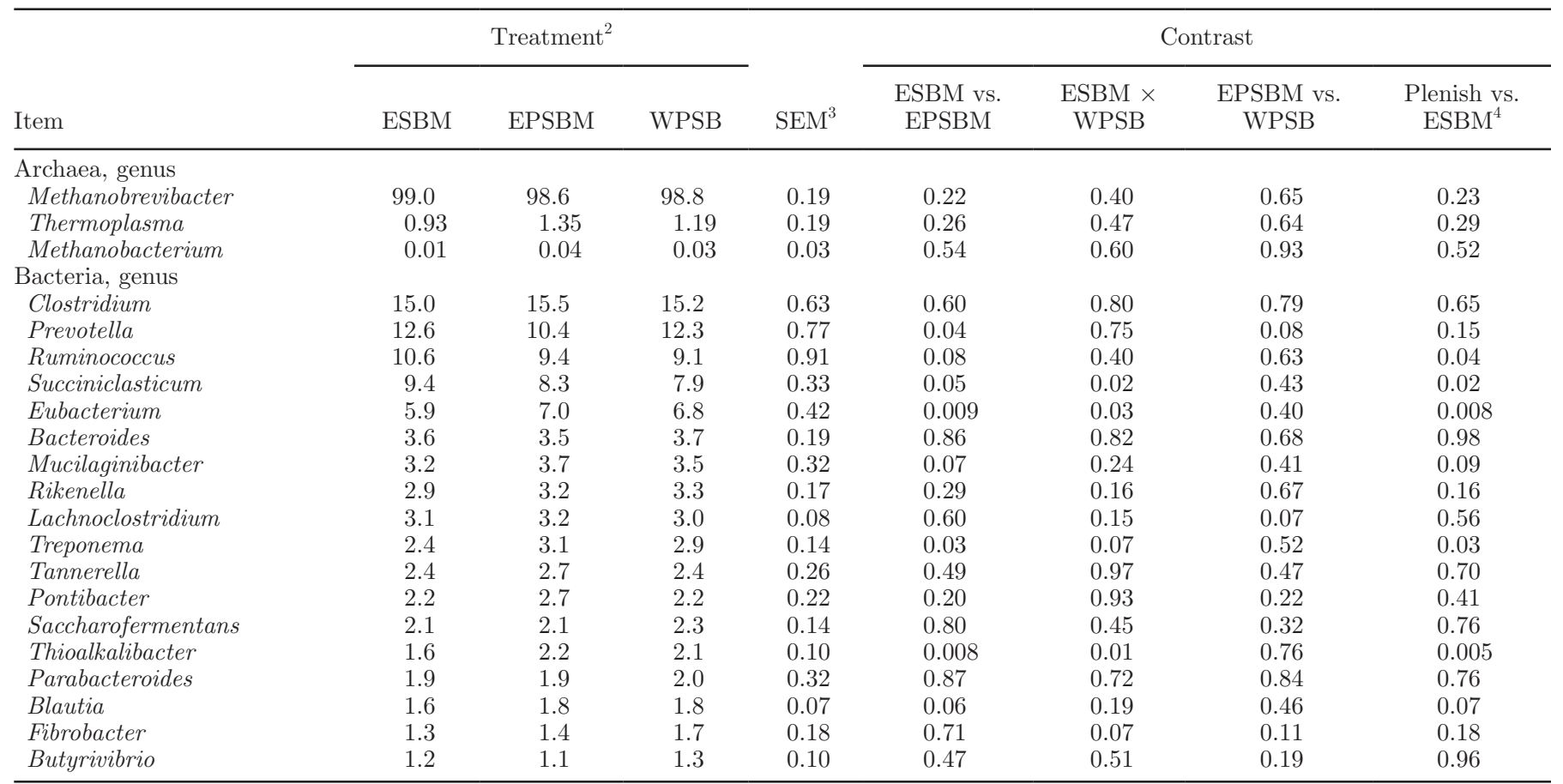

${ }^{1}$ The percentage represents the percentage of the total sequences analyzed within the sample.

${ }^{2} \mathrm{ESBM}=$ conventional variety extruded soybean meal; EPSBM $=$ Plenish variety extruded soybean meal; WPSB $=$ Plenish variety whole, heated soybeans.

${ }^{3}$ Largest SEM published in table. $\mathrm{n}=18$ for all variables (n represents the number of observations used in the statistical analysis). Data are presented as LSM.

${ }^{4}$ EPSBM and WPSB vs. ESBM. 
propionate concentration with WPSB compared with ESBM. The significance of the increased prevalence of Eubacterium with the Plenish diets cannot be determined. Acetogenic, hydrogenotrophic (Genthner et al., 1981), and hyper-ammonia producing (Wallace et al., 2003) species of Eubacterium have been identified in the rumen, but acetate or ammonia concentrations and methane and hydrogen emissions were not different among treatment in the current study. The reason for the increased proportion of Thioalkalibacter, a sulfur-oxidizing bacterium found in hypersaline soda lakes (Banciu et al., 2008), with the Plenish diets is also unclear. In our earlier study, ESBM processed at 2 different temperatures only numerically decreased the proportion of Ruminococcus and Succiniclasticum and had no effect on Thioalkalibacter when compared with solvent-extracted SBM (Giallongo et al., 2015).

Milk fatty acid data are shown in Table 9. Concentration of 6:0 and 10:0 were slightly decreased $(P \leq$ $0.03)$ and that of $14: 1$ was increased $(P=0.002)$ by the Plenish diets compared with ESBM. The ratio 14:1 to $(14: 1+14: 0)$ (i.e., 14:0 desaturase index) was increased $(P<0.001)$ by the Plenish diets compared with the control by $0.67,0.65$, and $0.60 \%$ (EPSBM, and WPSB, and ESBM, respectively; data not shown in Table 9). Overall, concentrations of fatty acids synthesized de novo in the mammary gland were not affected by diet; the sum of fatty acids $<16$ was similar among diets, and so was 16:0 $(P>0.06)$. Concentrations of 16:1, 17:1, and 17:0 iso were slightly increased $(P<0.001)$ and the sum of trans-fatty acids was markedly decreased $(P<$ 0.001) by the Plenish diets compared with the control. With a few insignificant exceptions, concentrations of most trans-18:1 fatty acids were decreased $(P<0.001)$ by the Plenish diets. Concentration of cis-9 18:1 was increased $(P<0.001)$ by $16 \%$ as a result of inclusion of the Plenish soybean sources in the diet. As expected, concentrations of 18:2 and cis-9,trans-11 CLA were lower $(P<0.001)$ for the Plenish diets compared with ESBM. Overall, treatment had no effect on the sum of SFA and, compared with ESBM, EPSBM and WPSB increased $(P<0.001)$ the sum of MUFA and decreased $(P<0.001)$ that of PUFA, trans-fatty acids, and CLA in milk fat.

Differences in milk fatty acid composition between ESBM and the Plenish soybean sources in our study were mainly due to the considerably lower 18:2 (and 18:3) and higher 18:1 in the Plenish soybean variety. Dietary fat intake was higher for WPSB versus the ESBM and EPSBM diets, which may have also been responsible for some of the milk fatty acid changes, such as increased 18:2 and 18:3 with WPSB versus EPSBM. The increase in cis-9 18:1 with the Plenish treatments is explained by the higher intake of this fatty acid with the EPSBM and WPSB diets, compared with ESBM, and has been reported in the literature (He and Armentano, 2011; Kliem et al., 2011) and in a meta-analysis by Glasser et al. (2008). Milk 18:1 is, to a large extent, a result of desaturation of $18: 0$ by $\Delta^{9}$-desaturase (Bickerstaffe et al., 1974; Chilliard et al., 2001), and the increased desaturase activity with the Plenish diets (see above) has likely also contributed to the greater concentration of milk cis-9 18:1 with EPSBM and WPSB compared with the control. The reduction of most trans-18:1 fatty acids with the Plenish diets is also explained by the lower intake of 18:2 with these diets compared with ESBM. Some trans-18:1 fatty acids, however, were increased by EPSBM and WPSB and this is in line with reports that biohydrogenation of 18:1 by the rumen microbes results in the formation of several trans 18:1 isomers (Mosley et al., 2002). Overall, the changes in milk fatty acid composition observed in the current study represent the greater dietary intake of 18:1 with the Plenish diets versus greater 18:2 intake with the conventional extruded SBM diet.

\section{CONCLUSIONS}

In this experiment, diets with Plenish (high-18:1) variety extruded SBM or whole, heated soybeans tended to increase DMI and decreased feed efficiency (but had no effect on ECM feed efficiency) in dairy cows compared with the conventional (high-18:2) extruded SBM diet. The Plenish diets increased milk fat concentration and tended to increase milk fat yield. Compared with the extruded SBM diets, the whole, heated soybeans diet had lower DM, OM, and CP total-tract digestibility, likely as a result of the processing method. Treatment had no effect on rumen fermentation or enteric methane emission. The Plenish diets increased MUFA and cis-9 18:1 and decreased PUFA, total trans-, and cis-9,trans-11 CLA concentrations in milk fat. Overall, diets modified milk fatty acid profile in a manner expected from the greater concentration of 18:1 in Plenish soybean oil. We conclude that oilseeds with higher 18:1 concentration in their oil are likely to increase milk fat concentration and yield and 18:1 content of milk in dairy cows, compared with oils with higher concentration of 18:2.

\section{ACKNOWLEDGMENTS}

This project was partially supported by funds from the Pennsylvania Soybean Board (Harrisburg, PA). The authors thank Fabin Bros. Farms for growing the Plenish soybeans and providing the extruded SBM for the experiment, DuPont Pioneer (Johnston, IA) for providing the Plenish soybean seeds, Kevin Harvatine's 
Table 9. Effect of soybean fatty acid composition and processing method on milk fatty acid composition ( $\mathrm{g} / 100 \mathrm{~g}$ of total fatty acids) in dairy cows

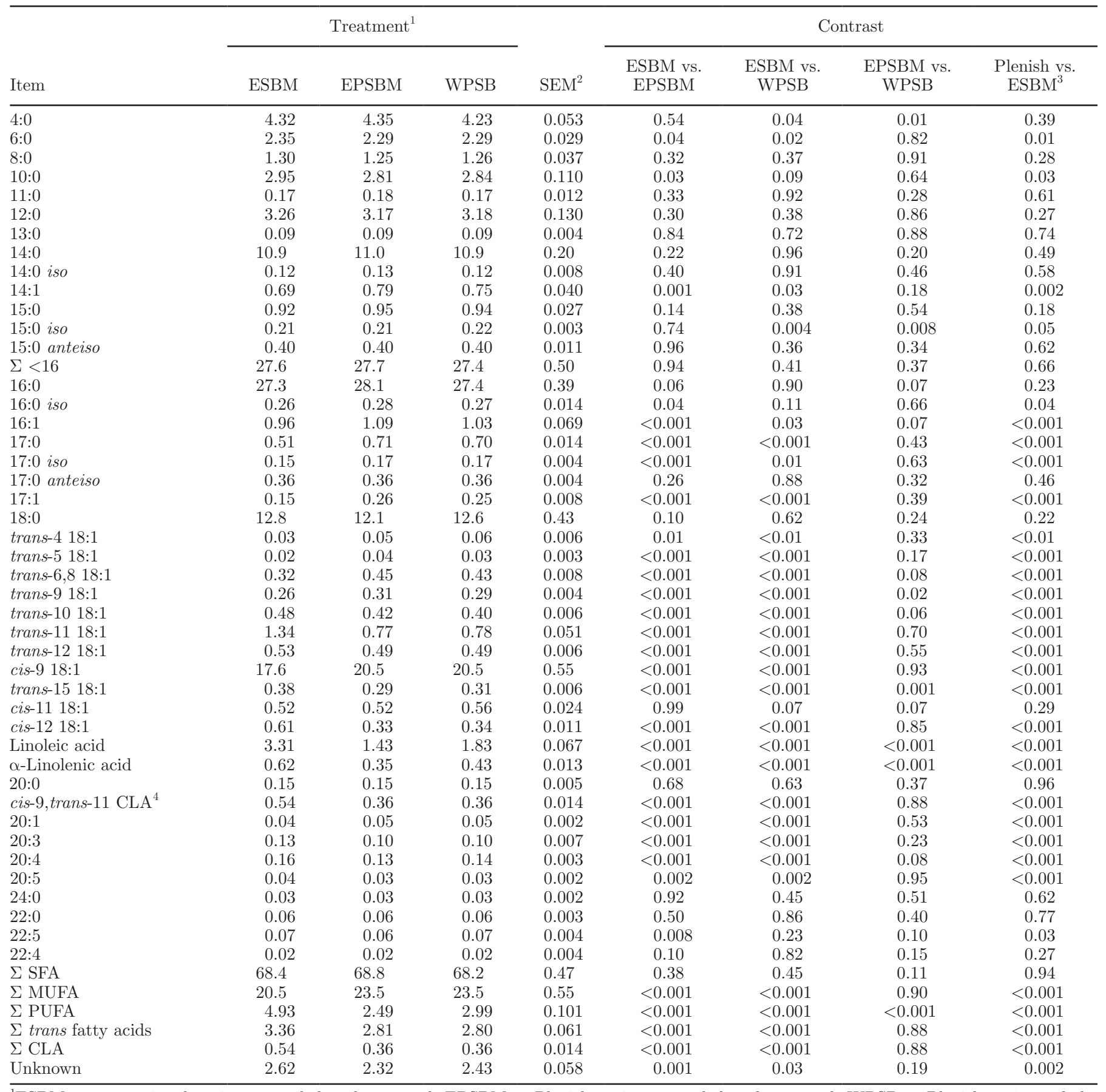

${ }^{1} \mathrm{ESBM}=$ conventional variety extruded soybean meal; EPSBM = Plenish variety extruded soybean meal; WPSB = Plenish variety whole, heated soybeans.

${ }^{2}$ Largest SEM shown; $\mathrm{n}=42$ for all variables ( $\mathrm{n}$ represents number of observations used in the statistical analysis). Data are presented as LSM. ${ }^{3} \mathrm{EPSBM}$ and WPSB vs. ESBM.

${ }^{4}$ trans-10, cis-12 C18:2 was not detected in this experiment.

laboratory (The Pennsylvania State University) for assisting with the milk and soybeans fatty acid analyses, and the staff of the Department of Animal Science
Dairy Research and Teaching Center at The Pennsylvania State University for their conscientious care of the experimental cows. 


\section{REFERENCES}

AOAC International. 2000. Official Methods of Analysis. 17th ed AOAC International, Arlington, VA.

AOAC International. 2006. Official Methods of Analysis. 18th ed. AOAC International, Arlington, VA.

Banciu, H. L., D. Y. Sorokin, T. P. Tourova, E. A. Galinski, M. S. Muntyan, J. G. Kuenen, and G. Muyzer. 2008. Influence of salts and $\mathrm{pH}$ on growth and activity of a novel facultatively alkaliphilic, extremely salt-tolerant, obligately chemolithoautotrophic sufuroxidizing Gammaproteobacterium Thioalkalibacter halophilus gen. nov., sp. nov. from south-western Siberian soda lakes. Extremophiles 12:391-404

Bauman, D. E., and J. M. Griinari. 2003. Nutritional regulation of milk fat synthesis. Annu. Rev. Nutr. 23:203-227.

Baumgard, L. H., B. A. Corl, D. A. Dwyer, A. Saebo, and D. E. Bauman. 2000. Identification of the conjugated linoleic acid isomer that inhibits milk fat synthesis. Am. J. Physiol. Regul. Integr. Comp. Physiol. 278:R179-R184.

Beauchemin, K. A., S. M. McGinn, C. Benchaar, and L. Holtshausen 2009. Crushed sunflower, flax, or canola seeds in lactating dairy cow diets: Effects on methane production, rumen fermentation, and milk production. J. Dairy Sci. 92:2118-2127.

Bickerstaffe, R., E. F. Annison, and J. L. Linzell. 1974. The metabolism of glucose, acetate, lipids and amino acids in lactating dairy cows. J. Agric. Sci. 82:85-90.

Casper, D. P., D. J. Schingoethe, R. P. Middaugh, and R. J. Baer. 1988. Lactational responses of dairy cows to diets containing regular and high oleic acid sunflower seeds. J. Dairy Sci. 71:1267-1274.

Chilliard, Y., A. Ferlay, and M. Doreau. 2001. Contrôle de la qualité nutritionnelle des matières grasses du lait par l'alimentation des vaches laitières: Acides gras trans, polyinsaturés, acide linoléique conjugué. INRA Prod. Anim. 14:323-335.

Chouinard, P. Y., V. Girard, and G. J. Brisson. 1997. Performance and profiles of milk fatty acids of cows fed full fat, heat-treated soybeans using various processing methods. J. Dairy Sci. 80:334-342.

DePeters, E. J., J. B. German, S. J. Taylor, S. T. Essex, and H. PerezMonti. 2001. Fatty acid and triglyceride composition of milk fat from lactating Holstein cows in response to supplemental canola oil. J. Dairy Sci. 84:929-936.

Doreau, M., C. Martin, M. Eugène, M. Popova, and D. P. Morgavi. 2011. Leviers d'action pour réduire la production de méthane entérique par les ruminants. Pages 461-474 in Gaz à Effet de Serre en Élevage Bovin: Le Méthane. M. Doreau, R. Baumont, and J. M. Perez, ed. Dossier, INRA Prod. Anim., Paris, France.

Faldet, M. A., and L. D. Satter. 1991. Feeding heat-treated full fat soybeans to cows in early lactation. J. Dairy Sci. 74:3047-3054.

Genthner, B. R., C. Davis, and M. P. Bryant. 1981. Features of rumen and sewage sludge strains of Eubacterium limosum, a methanoland $\mathrm{H}_{2}-\mathrm{CO}_{2}$-utilizing species. Appl. Environ. Microbiol. 42:12-19.

Giallongo, F., T. Frederick, J. Oh, B. Isenberg, D. M. Kniffen, A N. Hristov, and R. A. Fabin. 2015. Extruded soybean meal increased feed intake and milk production in dairy cows. J. Dairy Sci. 98:6471-6485.

Giallongo, F., M. Harper, J. Oh, J. Lopes, H. Lapierre, R. A. Patton, I. Shinzato, C. Parys, and A. N. Hristov. 2016. Effects of rumen-protected methionine, lysine and histidine on lactation performance of dairy cows. J. Dairy Sci. 99:4437-4452.

Glasser, F., A. Ferlay, and Y. Chilliard. 2008. Oilseed lipid supplements and fatty acid composition of cow milk: A meta-analysis. J. Dairy Sci. 91:4687-4703.

Grainger, C., and K. A. Beauchemin. 2011. Can enteric methane emissions from ruminants be lowered without lowering their production? Anim. Feed Sci. Technol. 166-167:308-320.

Griinari, J. M., D. A. Dwyer, M. A. McGuire, D. F. Bauman, D. L. Palmquist, and K. V. V. Nurmela. 1998. Trans-octadecenoic acids and milk fat depression in lactating dairy cows. J. Dairy Sci. 81:1251-1261.

Hall, M. B. 2009. Determination of starch, including maltooligosaccharides, in animal feeds: Comparison of methods and a method recommended for AOAC collaborative study. J. AOAC Int. 92:42-49.
Harfoot, C. G., and G. P. Hazlewood. 1997. Lipid metabolism in the rumen. Pages 382-426 in the Rumen Microbial Ecosystem. P. N. Hobson and C. S. Stewart, ed. Blackie Academic and Professional, London, UK.

He, M., and L. E. Armentano. 2011. Effect of fatty acid profile in vegetable oils and antioxidant supplementation on dairy cattle performance and milk fat depression. J. Dairy Sci. 94:2481-2491.

He, M., K. L. Perfield, H. B. Green, and L. E. Armentano. 2012. Effect of dietary fat blend enriched in oleic or linoleic acid and monensin supplementation on dairy cattle performance, milk fatty acid profiles, and milk fat depression. J. Dairy Sci. 95:1447-1461.

Henderson, C. 1973. The effects of fatty acids on pure cultures of rumen bacteria. J. Agric. Sci. 81:107-112.

Hinrichsen T, A. L. Lock, and D. E. Bauman. 2006. The relationship between trans-10 18:1 and milk fat yield in cows fed high oleic acid or high linoleic acid plant oil supplements. Euro-Fed Lipid Congress, October 2006. Madrid, Spain. (Abstr.)

Hristov, A. N., C. Domitrovich, A. Wachter, T. Cassidy, C. Lee, K J. Shingfield, P. Kairenius, J. Davis, and J. Brown. 2011a. Effect of replacing solvent-extracted canola meal with high-oil traditional canola, high-oleic acid canola, or high-erucic acid rapeseed meals on rumen fermentation, digestibility, milk production, and milk fatty acid composition in lactating dairy cows. J. Dairy Sci. 94:4057-4074.

Hristov, A. N., M. Ivan, and T. A. McAllister. 2004b. In vitro effects of individual fatty acids on protozoal numbers and on fermentation products in ruminal fluid from cattle fed a high concentrate, barley-based diet. J. Anim. Sci. 82:2693-2704.

Hristov, A. N., C. Lee, T. Cassidy, M. Long, K. Heyler, B. Corl, and R. Forster. 2011b. Effects of lauric and myristic acids on ruminal fermentation, production, and milk fatty acid composition in lactating dairy cows. J. Dairy Sci. 94:382-395.

Hristov, A. N., J. Oh, F. Giallongo, T. Frederick, M. Harper, H. Weeks, A. Branco, P. Moate, M. Deighton, R. Williams, M. Kindermann, and S. Duval. 2015b. An inhibitor persistently decreased enteric methane emission from dairy cows with no negative effect on milk production. Proc. Natl. Acad. Sci. USA 112:10663-10668. https:// doi.org/10.1073/pnas.1504124112.

Hristov, A. N., J. Oh, F. Giallongo, T. Frederick, M. T. Harper, H. Weeks, A. F. Branco, W. J. Price, P. J. Moate, M. H. Deighton, S. R. O. Williams, M. Kindermann, and S. Duval. 2016. Short communication: Comparison between the GreenFeed system and the sulfur hexafluoride tracer technique for measuring enteric methane emissions from dairy cows. J. Dairy Sci. 99:5461-5465.

Hristov, A. N., J. Oh, F. Giallongo, T. Frederick, H. Weeks, P. R Zimmerman, R. A. Hristova, S. R. Zimmerman, and A. F. Branco. 2015a. The use of an automated system (GreenFeed) to monitor enteric methane and carbon dioxide emissions from ruminant animals. J. Vis. Exp. 103:e52904.

Hristov, A. N., W. J. Price, and B. Shafii. 2004a. A meta-analysis examining the relationship among dietary factors, dry matter intake, and milk yield and milk protein yield in dairy cows. J. Dairy Sci. 87:2184-2196.

Hristov, A. N., G. Varga, T. Cassidy, M. Long, K. Heyler, S. K. R. Karnati, B. Corl, C. J. Hovde, and I. Yoon. 2010. Effect of Saccharomyces cerevisiae fermentation product on ruminal fermentation and nutrient utilization in dairy cows. J. Dairy Sci. 93:682-692.

Huhtanen, P., M. Rinne, and J. Nousiainen. 2009. A meta-analysis of feed digestion in dairy cows. 2. The effects of feeding level and diet composition on digestibility. J. Dairy Sci. 92:5031-5042.

Jenkins, T. C. 1993. Lipid metabolism in the rumen. J. Dairy Sci $76: 3851-3863$

Jenkins, T. C., and M. A. McGuire. 2006. Major advances in nutrition: Impact on milk composition. J. Dairy Sci. 89:1302-1310.

Kelly, M. L., J. R. Berry, D. A. Dwyer, J. M. Griinari, P. Y. Chouinard, M. E. Van Amburgh, and D. E. Bauman. 1998. Dietary fatty acid sources affect conjugated linoleic acid concentrations in milk from lactating dairy cows. J. Nutr. 128:881-885.

Kliem, K. E., K. J. Shingfield, D. J. Humphries, and D. I. Givens 2011. Effect of replacing calcium salts of palm oil distillate with incremental amounts of conventional or high oleic acid milled rape- 
seed on milk fatty acid composition in cows fed maize silage-based diets. Animal 5:1311-1321.

Krishnamoorthy, U., C. J. Sniffen, M. D. Stern, and P. J. Van Soest. 1983. Evaluation of a mathematical model of rumen digestion and an in vitro simulation of rumen proteolysis to estimate the rumenundegraded nitrogen content of feedstuffs. Br. J. Nutr. 50:555-568.

Lee, C., A. N. Hristov, T. W. Cassidy, K. S. Heyler, H. Lapierre, G. A. Varga, M. J. de Veth, R. A. Patton, and C. Parys. 2012. Rumen protected lysine, methionine, and histidine increase milk protein yield in dairy cows fed a metabolizable protein-deficient diet. J. Dairy Sci. 95:6042-6056.

Lee, C., A. N. Hristov, K. S. Hyler, T. W. Cassidy, M. Long, B. A. Corl, and S. K. R. Karnati. 2011. Effects of dietary protein concentration and coconut oil supplementation on nitrogen utilization and production in dairy cows. J. Dairy Sci. 94:5544-5557.

Lock, A. L., C. Tyburczy, D. A. Dwyer, K. J. Harvatine, F. Destaillats, M. Mouloungui, L. Candy, and D. E. Bauman. 2007. Trans-10 octadecenoic acid does not reduce milk fat synthesis in dairy cows. J. Nutr. 137:71-76.

Lopes, J. C. L. F. de Matos, M. T. Harper, F. Giallongo, J. Oh, D. Gruen, S. Ono, M. Kindermann, S. Durval, and A. N. Hristov. 2016. Effect of 3-nitrooxipropanol on ruminal fermentation, methane and hydrogen emissions, and methane isotopic signature in dairy cows. J. Dairy Sci. 99:5335-5344.

Maczulak, A. E., B. A. Dehority, and D. L. Palmquist. 1981. Effects of long-chain fatty acids on growth of rumen bacteria. Appl. Environ. Microbiol. 42:856-862.

Maia, M. R. G., L. C. Chaudhary, C. S. Bestwick, A. J. Richardson, N. McKain, T. R. Larson, I. A. Graham, and R. J. Wallace. 2010 Toxicity of unsaturated fatty acids to the biohydrogenating ruminal bacterium, Butyrivibrio fibrisolvens. BMC Microbiol. 10:52. https://doi.org/10.1186/1471-2180-10-52.

Moate, P. J., W. Chalupa, R. C. Boston, and I. J. Lean. 2008. Milk fatty acids. II: Prediction of the production of individual fatty acids in bovine milk. J. Dairy Sci. 91:1175-1188.

Mosley, E. E., G. L. Powell, M. B. Riley, and T. C. Jenkins. 2002 Microbial biohydrogenation of oleic acid to trans isomers in vitro. J. Lipid Res. 43:290-296.

NRC. 2001. Nutrient Requirements of Dairy Cattle. 7th rev. ed. Natl. Acad. Sci., Washington, DC

Nydam, D.V., T.R. Overton, D.E. Bauman, T.C. Jenkins, and G.D Mechor. 2009. Field study to investigate the risk factors for milk fat depression (MFD) in dairy herds feeding Rumensin. J. Dairy Sci. 92(E. Suppl. 1):285. (Abstr.)

Onetti, S. G., and R. R. Grummer. 2004. Response of lactating cows to three supplemental fat sources as affected by forage in the diet and, stage of lactation: A meta-analysis of literature. Anim. Feed Sci. Technol. 115:65-82.

Palmquist, D. L. 1991. Influence of source and amount of dietary fat on digestibility in lactating cows. J. Dairy Sci. 74:1354-1360.

Patra, A. K. 2013. The effect of dietary fats on methane emissions, and its other effects on digestibility, rumen fermentation and lactation performance in cattle: A meta-analysis. Livest. Sci. 155:244-254.

Rabiee, A. R., K. Breinhild, W. Scott, H. M. Golder, E. Block, and I. J. Lean. 2012. Effect of fat additions to diets of dairy cattle on milk production and components: A meta-analysis and metaregression. J. Dairy Sci. 95:3225-3247.

Rico, D. E., and K. J. Harvatine. 2013. Induction of and recovery from milk fat depression occurs progressively in dairy cows switched between diets that differ in fiber and oil concentration. J. Dairy Sci. 96:6621-6630.

Santos, F. A. P., J. E. P. Santos, C. B. Theurer, and J. T. Huber. 1998 Effects of rumen-undegradable protein on dairy cow performance: A 12-year literature review. J. Dairy Sci. 81:3182-3213.

Schroeder, G. F., G. A. Gagliostro, F. Bargo, J. E. Delahoy, and L. D. Muller. 2004. Effects of fat supplementation on milk production and composition by dairy cows on pasture: a review. Livest. Prod. Sci. 86:1-18.

Scott, T. A., D. K. Combs, and R. R. Grummer. 1991. Effects of roasting, extrusion, and particle size on the feeding value of soybeans for dairy cows. J. Dairy Sci. 74:2555-2562.

Sjaunja, L. O., L. Baevre, L. Junkkarinen, J. Pedersen, and J. Setälä. 1990. A Nordic proposal for an energy corrected milk (ECM) formula. Proc. 27th Session Int. Comm. Breeding Product. Milk Anim., Paris, France. Wageningen Acad. Publ., Wageningen, the Netherlands

Socha, M. 1991. Effect of heat-processed whole soybeans on milk production, milk composition, and milk fatty acid profile. MS Thesis. Department of Dairy Science, Univ. of Wisconsin, Madison.

Stoffel, C. M., P. M. Crump, and L. E. Armentano. 2015. Effect of dietary fatty acid supplements, varying in fatty acid composition, on milk fat secretion in dairy cattle fed diets supplemented to less than 3\% total fatty acids. J. Dairy Sci. 98:431-442.

Szumacher-Strabel, M., A. Potkański, J. Kowalczyk, A. Cieślak, M. Czauderna, A. Gubała, and P. Jędroszkowiak. 2002. The influence of supplemental fat on rumen volatile fatty acid profile, ammonia and $\mathrm{pH}$ levels in sheep fed a standard diet. J. Anim. Feed Sci. 11:577-587.

van Gylswyk, N. O. 1995. Succiniclasticum ruminis gen. nov., sp. nov., a ruminal bacterium converting succinate to propionate as the sole energy-yielding mechanism. Int. J. Syst. Bacteriol. 45:297-300.

Van Soest, P. J., J. B. Robertson, and B. A. Lewis. 1991. Methods for dietary fiber, neutral detergent fiber, and nonstarch polysaccharides in relation to animal nutrition. J. Dairy Sci. 74:3583-3597.

Wallace, R. J., N. McKain, N. R. McEwan, E. Miyagawa, L. C Chaudhary, T. P. King, N. D. Walker, J. H. Apajalahti, and C. J. Newbold. 2003. Eubacterium pyruvativorans sp. nov., a novel nonsaccharolytic anaerobe from the rumen that ferments pyruvate and amino acids, forms caproate and utilizes acetate and propionate Int. J. Syst. Evol. Microbiol. 53:965-970.

Weiss, W. P., J. M. Pinos-Rodríguez, and D. J. Wyatt. 2011. The value of different fat supplements as sources of digestible energy for lactating dairy cows. J. Dairy Sci. 94:931-939.

Welter, K. C., C. M. Martins, A. S. de Palma, M. M. Martins, B. R dos Reis, B. L. Schmidt, and A. Saran Netto. 2016. Canola oil in lactating dairy cow diets reduces milk saturated fatty acids and improves its omega-3 and oleic fatty acid content. PLoS One 11:e0151876. https://doi.org/10.1371/journal.pone.0151876. 